\title{
The Effectiveness of Open-Ended Problems Based Analytic-Synthetic Learning on the Mathematical Creative Thinking Ability of Pre-Service Elementary School Teachers

\author{
Yeni Yuniarti ${ }^{a}$, Yaya S. Kusumaha ${ }^{a}$ Didi Suryadia and Bana G. \\ Kartasasmita ${ }^{a}$
}

andonesia University of Education, INDONESIA

\begin{abstract}
This study aims to analyze the achievement of mathematical creative thinking ability of pre-service elementary school teachers who received open-ended problems based analytic-synthetic learning and conventional learning. This study is a quasi-experimental research with pretest-posttest control group design to pre-service elementary school teachers in a state university of West Java with 136 students divided into two groups of research subjects, of 68 students each. The instrument used in this research are prior mathematical knowledge test, mathematical creative thinking ability tests, and interview guidance. The results of data analysis using statistic of parametric and nonparametric showed that: 1) The Achievement mathematical creative thinking ability of students who received open-ended problems based learning analytic-synthetic better than those conventional learning is reviewed whole and each level prior mathematical knowledge as well; 2) the effect size of open-ended problems based analytic-synthetic learning on the achievement of students' mathematical creative thinking ability in high category. The research recommended that open-ended problems based analyticsynthetic learning can be used achievement of mathematical creative thinking ability.
\end{abstract}

KEYWORDS

Creative thinking, open-ended, analytic-synthetic

learning
ARTICLE HISTORY

Received 15 September 2017

Revised 10 October 2017

Accepted 12 October 2017

\section{Introduction}

Every educational system aims to encourage students to have creative ability. Similarly in Indonesia, the curriculum is constructed based on the principle that learners have a central position to develop their competence, one of which is to

\section{CORRESPONDENCE Yeni Yuniarti $\square$ yeni_yuniarti@upi.edu}

(c) 2017 Y. Yuniarti et al.

Open Access terms of the Creative Commons Attribution 4.0 International License apply. The license permits unrestricted use, distribution, and reproduction in any medium, on the condition that users give exact credit to the original author(s) and the source, provide a link to the Creative Commons license, and indicate if they made any changes. (http://creativecommons.org/licenses/by/4.0/) 
become a creative human being (BSNP, 2006). According to C.J. Neumann (2007) that throughout human history, creativity is considered the driving force behind all innovation. Therefore, in the context of the 21st century, the key skills that must be possessed are learning and innovation skills that include creative thinking skills and problem-solving skills, communication and collaboration skills, and creativity and innovation skills (Trilling \& Fadel, 2009). In parallel with it the National Research Council (2012) places creativity on one of the three domains of competence in this century, the cognitive domain that involves reasoning and memory that includes three groups of competencies: cognitive processes and strategies; knowledge; and creativity.

Therefore, in order to be creative, schools should develop an appropiate environment for teachers and students (Starko, 2014). In school mathematics learning should offer more than procedural skills (Hyman, 1993). Mathematical creativity will be difficult to develop if one is limited to rule-based implementation without recognizing the essence of the problem to be solved (Mann, 2006). It is the duty of a teacher in class to equip students not only about rules and procedures, but also emphasize creative ways to express ideas in solving math problems. This is in line with K. Suastika (2017) that teachers of mathematics are required to develop students' creativity in the learning that is done, so that students are able to build their mathematical talents. Hence, the competence of teachers and the creation of teaching and learning environment are two important things in improving students' mathematical creative thinking ability. Furthermore, limited knowledge of teachers will be detrimental and can affect the creativity and flexibility of teachers in preparing the teaching and learning environment (Celik \& Arslan, 2012). Conversely, prospective teachers who have a high value on the nature of openness and have more experience related to creativity are more likely to support the creative style of teaching (Lee \& Kemple, 2014). Thus, only creative teachers can train creative students (Nadjafikhah, Yaftian, \& Bakhshalizadeh, 2012).

U. Munandar (2003) asserted that the optimal development of creative thinking ability is closely related to the way of teaching. However, much of the formal education only emphasizes convergent thinking (Munandar, 2014). Students should be given the opportunity to engage in struggling solving challenging mathematical problems that lead students to experience and creativity in mathematics and try to think like a mathematician, meaning that students are encouraged to reflect on their own ideas (Nadjafikhah \& Yaftian, 2013). Similarly, B. Sriraman (2005) states that most curriculum and educational approaches ignore open-ended views in the mathematics class and do not apply open-ended problems and avoid giving students the opportunity to engage in these types of issues independently in the long time. Though experience with open problems gives students an opportunity to express their conceptual understanding (Mann, 2006).

Actually creative thinking is the essence in mathematics (Mann 2006). Creative thinking mathematically refers to the ability to produce new, varied solutions to open-ended mathematical problems (Johnson 2000; Livne, 2008). Meanwhile Grieshober (2004), defines it as an idea construction process that emphasizes fluency, flexibility, originality, and elaboration. However, some studies show that students' creative thinking ability in mathematics is still not as expected. As the result of research of Supriadi (2014) shows that the ability of 
mathematical creative thinking of elementary school teacher candidate on flexibility aspect get the highest result but in the fluency aspect get the lowest result. Difficulties occur because students are accustomed to the inductive way, so when presented the problem is deductive, students have difficulty to solve it. A. Suryana (2016) in his research mentioned that the achievement of student's ability in the indicator of creative thinking that is originality is considered low based on the learning group (experiment and control) and reviewed based on the level of early mathematical knowledge. Based on these findings, the training of students as prospective teachers and creating a creative environment is one of the needs that must be done and considered.

Open-ended problems based analytic-synthetic learning is one of the learning approaches involving students in analytic and synthetic activities towards open-ended problems to develop the ability of mathematical creative thinking. This study involves three very important intellectual skills and each one related to each other, namely (a) the synthetic skill to see the problems in the battle of conventional thinking, (b) the analytic skill to recognize which of one's Ideas are worth pursuing and which are not, and (c) the practicalcontextual skills of knowing how to persuade others of-the value of one's ideas (Sternberg, 2006). Lessons that are designed in small groups heterogeneously require students to work collaboratively. When this process occurs, students interact, communicate, share ideas, appreciate each other, and understand different opinions. Another characteristic in this study is the existence of intervention in the form of giving the question in a convergent or divergent. This questioning is important because according to Dillon (Chamberlin \& Moon, 2005), questions are a core function of learning and teaching, and through questioning students will be encouraged to think at higher cognitive levels. Similarly, M. Shahrill and D.J. Clarke (2014) revealed that the question as part of the teaching tool is a good strategy to motivate and challenge students' thinking, so that interaction can occur in the learning process in the classroom.

Based on this thinking, this study aims to examine in depth the achievement of the ability to think creatively mathematically prospective elementary school teachers who obtain open-ended problems based analyticalsynthetic learning and conventional learning reviewed in whole and viewed from prior mathematical knowledge level (high, medium, and low). Attention to prior mathematical knowledge of students is done because according to Ausubel that the single most important factor affecting learning is what is already known to students (Hailikari, 2009). The knowledge already possessed is part of the student's prior knowledge which can be either correct conceptions, misconceptions, or naïve theories. The schemata of these students will grow and develop like new information during the learning process (Chareka, 2010). In addition, this study also aims to determine the effectiveness of open-ended problems based analytical-synthetic learning on the achievement of students' mathematical creative thinking ability.

\section{Method}

\section{Design Research}

This research is a quasi experiment with non-equivalent control group design. Research units are determined based on the category of students' prior mathematical knowledge (PMK) with three levels, namely high, medium, and 
low, and the learning-based category (open-ended problems based analyticsynthetic and conventional). The subjects of the study were pre-service elementary school teachers at one of the state universities in Indonesia with 136 students divided into two groups of research subjects, of 68 students each. Students who obtain open-ended problems based analytic-synthetic learning called the experimental group and students who receive conventional teaching called the control group.

Forward to the study, all students were given a test to measure the prior mathematical knowledge (PMK) and the results of these tests were then grouped into high, medium, and low levels. Determination of PMK (high, medium, and low) criteria was arranged using S. Arikunto (2005) grouping rules with $x \geq \bar{x}+s d$ including high level, $\bar{x}-s d \leq x<\bar{x}+s d$ including medium level, and $x \leq \bar{x}-s d$ including low level. In detail, the description of the PMK levels of students (high, medium, and low) in both learning (experiment dan control) can be seen from the mean and standard deviations in the following table.

Table 1. Results of PMK Tests on Both Learning Groups

\begin{tabular}{cccccccc}
\hline & & \multicolumn{6}{c}{ Learning Groups } \\
\cline { 3 - 8 } & & & \multicolumn{3}{c}{ Experiment } & \multicolumn{4}{c}{ control } \\
\cline { 3 - 8 } & & $n$ & $\bar{x}$ & sd & $N$ & $\bar{x}$ & Sd \\
\hline \multirow{3}{*}{ PMK Level } & High & 13 & 15.77 & 1.58 & 10 & 15.60 & 1.20 \\
& Medium & 42 & 11.31 & 2.37 & 48 & 11.15 & 2.30 \\
& Low & 13 & 4.85 & 1.29 & 10 & 4.00 & 2.00 \\
\hline
\end{tabular}

In Table 1, the average value $(\bar{x})$ and standard deviation ( $s d)$ of PMK tests at the high, medium and low levels of the experimental and control group did not differ greatly. Average difference of high level 0.17, medium level 0.16, and low level 0.85 , with the difference of standard deviation respectively that is 0.67 , 0.07 , and 0.71 . These results indicate that the student's prior mathematical knowledge (PMK) condition is relatively the same.

The result of prerequisite analysis test shows that the PMK score in the two study groups is not normally distributed, so the Mann-Whitney test is performed as shown in the following table.

Table 2. Mann-Whitney's test of prior mathematical knowledge of students

\begin{tabular}{cccc}
\hline Learning Group & Mann-Whitney U & Z & Sig. \\
\hline $\begin{array}{c}\text { Eksperiment } \\
\text { Control }\end{array}$ & 2234,500 & $-0,339$ & 0,735 \\
\hline
\end{tabular}

Table 2 shows the Sig. value. $=0.735$ greater than $=0.05$, so there is no difference in prior mathematical knowledge (PMK) of students in both learning groups. This condition strengthens and qualifies different treatments in both research groups (experiments and controls), so that if there is a difference in achievement in the creative thinking ability in mathematics between the two learning groups, it is not caused by differences in the PMK of students but as a result of the treatment of each group.

\section{Instrument}

The instrument used in this research is prior mathematical knowledge test, 
mathematical creative thinking ability tests, and interview guidance. This test is conducted with the aim to find out to what extent the achievement of mathematical creative thinking ability of elementary school teacher candidates after obtaining open-ended problems based analytic-synthetic learning in the experimental class and conventional learning in the control class. The test is in the form of a description to measure aspects of mathematical creative thinking ability, namely fluency, flexibility, elaboration, and originality. The test used seven questions that have qualified test validity with a relatively high reliability is $r_{11}=0.89$. The next step of the research is giving the test of mathematical creative thinking ability in both groups (experiment and control). This test is given to prospective elementary school teachers before and after learning (pretest and posttest).

\section{Findings}

Analysis of posttest scores to measure students' mathematical creative thinking ability based on learning can be seen in Table 3 below.

Table 3. Score Posttest Students' Mathematical Creative Thinking Ability

\begin{tabular}{|c|c|c|c|c|c|c|c|c|c|c|c|}
\hline \multirow{2}{*}{\multicolumn{2}{|c|}{ Category }} & \multicolumn{5}{|c|}{ Experiment } & \multicolumn{5}{|c|}{ Control } \\
\hline & & $N$ & $\min$ & $\max$ & $\bar{x}$ & Sd & $N$ & $\min$ & $\max$ & $\bar{x}$ & $s d$ \\
\hline \multicolumn{2}{|c|}{ Learning Model } & 68 & 25 & 45 & 33.19 & 4.63 & 68 & 11 & 37 & 26.51 & 5.78 \\
\hline \multirow{3}{*}{$\begin{array}{c}\text { PMK } \\
\text { Level }\end{array}$} & High & 13 & 37 & 45 & 40.77 & 2.49 & 10 & 31 & 37 & 34.10 & 1.91 \\
\hline & Medium & 42 & 26 & 37 & 32.14 & 2.50 & 48 & 22 & 33 & 27.15 & 2.48 \\
\hline & Low & 13 & 25 & 35 & 29.00 & 2.61 & 10 & 11 & 25 & 15.90 & 4.63 \\
\hline
\end{tabular}

Table 3 shows that the achievement of students' mathematical creative thinking abilities in the experimental group is higher than the control group. The achievement of students' mathematical creative thinking abilities in the experimental group for each PMK (high, medium and low) level was higher than the control group. Achievement of students' mathematical creative thinking ability low level in the experimental group is higher than medium level in the control group.

The results of the analysis indicate that open-ended problems based analytic-synthetic learning can further develop students' mathematical creative thinking skills at each PMK level rather than conventional learning. Mathematical creative thinking abilities of students at high level obtaining open-ended problems based analytic-synthetic learning are more developed than the level of medium and low level. Mathematical creative thinking abilities of students at the medium level is more developed than low level.

Before the test the average difference to the achievement of mathematical creative thinking ability of students in both groups as a whole and the level of PMK, first tested ie analysis prerequisite test for normality and homogenity.

Table 4. Normality Test on Data Achievement of Mathematical Creative Thinking Ability

\begin{tabular}{ccccc}
\hline \multirow{2}{*}{$\begin{array}{c}\text { Learning } \\
\text { Groups }\end{array}$} & & \multicolumn{3}{c}{ Kolmogorov-Smirnov } \\
\cline { 3 - 5 } & & Statistic & Df & Sig. \\
\cline { 3 - 5 } Experiment & Total & .131 & 68 & .006 \\
& High & .155 & 13 & .200 \\
& Medium & .113 & 42 & .200 \\
\hline
\end{tabular}




\begin{tabular}{lcccc}
\hline & Low & .264 & 13 & .013 \\
\hline \multirow{3}{*}{ Control } & Total & .161 & 68 & .000 \\
& High & .217 & 10 & .198 \\
& Medium & .116 & 48 & .118 \\
& Low & .234 & 10 & .127 \\
\hline
\end{tabular}

Based on Table 4, the data of students' mathematical creative thinking achievement in the experimental and control group obtained the sig score. $<.05$, so the data is not normally distributed. Meanwhile, data on the achievement of students' mathematical creative thinking level of high and medium level in both learning groups have sig. $>.05$, meaning that the sample is from a normally distributed population. At the low level, the experimental group obtained the sig score. $<.05$, meaning that the data is not normally distributed, while in the control group obtained sig. $>.05$ means that data is not normally distributed. Based on these results, a nonparametric test was performed using MannWhitney test in both study groups and at low level. Homogeneity of variance test was done in high and medium level before parametric test.

Table 5. Test of Homogenity of Variances

\begin{tabular}{ccccc}
\hline PMK level & Levene Statistic & $\mathbf{d f}_{1}$ & $\mathbf{d f}_{2}$ & Sig. \\
\hline High & .598 & 1 & 21 & .448 \\
Medium & .035 & 1 & 88 & .853 \\
\hline
\end{tabular}

Homogenity test results in Table 5. shows the value of sig. $>.05$, so the variance is homogeneous. Thus, the parametric test of achievement data of mathematical creative thinking ability at high and medium level is done by using t-test.

Nonparametric test results using Mann-Whitney test on the data of achievement of mathematical creative thinking ability based on learning reviewed in the whole can be seen in Table 6 below.

Table 6. Mann-Whitney Test of Data Achievement of Mathematical Creative Thinking Ability Based on Learning.

\begin{tabular}{cccc}
\hline Learning Groups & Mann-Whitney U & Z & Sig \\
\cline { 1 - 2 } Experiment & 789.500 & -6.642 & .000 \\
\hline Control & & & \\
\hline
\end{tabular}

Table 6 shows the sig value. $<.05$, it means that the achievement of students' mathematical creative thinking ability in experimental group is better than control group.

The result of parametric test with t-test on the achievement data of students' mathematical creative thinking ability from high and medium level in both study groups can be seen in the following table.

Table 7. T-test for Equality of Means Achievement of Students' Mathematical Creative Thinking Ability from High Level and Medium Level

\begin{tabular}{ll}
\hline PMK Level & $\begin{array}{l}95 \% \text { Confidence Interval of } \\
\text { the Difference }\end{array}$ \\
\hline
\end{tabular}




\begin{tabular}{lccccccc}
\hline & & & \multicolumn{2}{c}{$\begin{array}{l}\text { Mean } \\
\text { Difference }\end{array}$} & $\begin{array}{l}\text { Std. Error } \\
\text { Difference }\end{array}$ & Lower & Upper \\
\hline High & 7.017 & 21 & .000 & 6.669 & .950 & 4.693 & 8.646 \\
Medium & 9.502 & 88 & .000 & 4.997 & .526 & 3.952 & 6.042 \\
\hline
\end{tabular}

The result of calculation in Table 7 shows that the average value of achievement of mathematical creative thinking ability at high and medium level obtains sig value. $<.05$, so that the achievement of mathematical creative thinking ability of high and medium levels in experiment group is better than control group. Meanwhile, the Mann-Whitney test result of the achievement of student's mathematical creative thinking at low level can be seen in the following table.

Table 8. Mann-Whitney Test of Data Achievement of Student's Mathematical Creative Thinking Ability from Low Level

\begin{tabular}{ccccc}
\hline PMK Level & Learning Groups & Mann-Whitney U & Z & Sig \\
\cline { 2 - 2 } Low & Experiment & .500 & -4.041 & .000 \\
\hline
\end{tabular}

It can be seen in Table 8 that the value of sig. $<.05$, so that the achievement of students' mathematical creative thinking ability at low level in experimental group is better than control group.

The above results show that the achievement of the mathematical creative thinking ability of students who have open-ended problems based analyticsynthetic learning is significantly better than conventional learning when viewed in whole as well as from the PMK (high, medium, and low) levels.

As a complement to this research, calculations using the effect size of Cohen $d$ to determine the contribution of open-ended problems based analytic-synthetic learning to the achievement of students' mathematical creative thinking ability. The effect size calculation results are presented in Table 9 below.

Table 9. Effect Size Application of Learning to Achievement of Students' Mathematical Creative Thinking Ability

\begin{tabular}{ccccccc}
\hline Learning Groups & $\boldsymbol{n}$ & $\overline{\boldsymbol{x}}$ & $\boldsymbol{S}$ & $\boldsymbol{S}_{\text {pool }}$ & $\boldsymbol{d}$ & Interpretation \\
\hline Experiment & 68 & 33.19 & 4.63 & \multirow{2}{*}{5.24} & \multirow{2}{*}{1.28} & \multirow{2}{*}{ High } \\
Control & 68 & 26.51 & 5.78 & & & \\
\hline
\end{tabular}

Based on Table 9 , the value of $d=1.28$ belongs to the high category, meaning that the effect size (ES) of open-ended problems based analyticsynthetic learning on the achievement of students' mathematical creative thinking ability is in the high category.

More details of pretest and posttest results the ability of mathematical creative thinking is analyzed by its aspects. The goal is to provide a more specific picture of the student's work on pretest and postes that measure the ability of creative mathematical thinking on open-ended problems based analytic-synthetic learning and conventional learning. The average student work result is presented in the following table. 
Table 10. Average Student Work Outcomes from Every Aspect of Mathematical Creative Thinking Ability

\begin{tabular}{ccccc}
\hline \multirow{2}{*}{ Aspect } & \multicolumn{2}{c}{ Exsperiment } & \multicolumn{2}{c}{ Control } \\
\cline { 2 - 5 } & Pretest & Posttest & Pretest & Posttest \\
\hline Fluency & 1,51 & 2,85 & 1,47 & 2,44 \\
$(I S=4)$ & $(37,8 \%)$ & $(71,3 \%)$ & $(36,8 \%)$ & $(61,0 \%)$ \\
\hline Flexibility & 1,38 & 2,61 & 1,33 & 2,12 \\
$(I S=4)$ & $(34,5 \%)$ & $(65,3 \%)$ & $(33,3 \%)$ & $(53,0 \%)$ \\
\hline Elaboration & 1,27 & 2,60 & 1,21 & 2,19 \\
(IS $=4$ & $(31,8 \%)$ & $(65,0 \%)$ & $(30,3 \%)$ & $(54,8 \%)$ \\
\hline Originality & 0,35 & 2,05 & 0,49 & 1,27 \\
(IS $=4)$ & $(8,8 \%)$ & $(51,3 \%)$ & $(12,3 \%)$ & $(31,8 \%)$
\end{tabular}

Description: IS = Ideal Score

In Table 10, it can be seen that the average pretest of each aspect of students' mathematical creative thinking ability in the experimental group and control group is not too far away. This condition shows that before being treated, the students' mathematical creative thinking ability in every aspect is relatively the same. The achievement (posttest) of mathematical creative thinking based on its aspects in the experimental group is higher than the control group. The highest achievement in the experimental group and control group was on the fluency aspect and the lowest on the originality aspect. Overall, in open-ended problems based analytic-synthetic learning, the achievement of students' mathematical creative thinking ability on fluency aspect is high, while the other aspect is medium. In conventional learning, the achievement of creative thinking ability on the aspect of fluency, flexibility, and elaboration are medium, while in the aspect of novelty (originality) is low.

\section{Conclusion and Discussion}

The results of the analysis show that the achievement of students' mathematical creative thinking ability which get open-ended problems based analytic-synthetic learning is significantly better than students who get conventional learning. This finding is similar to that of T. Mulyana (2008), Risnanosanti (2010), S.H. Noer (2011), Kartini (2011), W. Khoiri, A. Rochmad, A.N. Cahyono (2013), Kumiati (2014) who found that although the achievement of mathematical creative thinking ability of students who acquired innovative learning has not been optimal, but the achievement of students' mathematical creative thinking ability in innovative learning is better than conventional learning. These results suggest that open-ended problems based analyticsynthetic learning provides a stronger effect on the achievement of students' mathematical creative thinking abilities than conventional learning. This result is reinforced by the effect size of open-ended problems based analytic-synthetic learning to the achievement of students' mathematical creative thinking ability in high category.

These findings may occur because, according N. Nohda (2000) giving an open-ended problem in mathematics have no purpose to obtain the correct answer, but to help develop the mindset and creative mathematical activity of students. It is therefore not surprising that the analytic-synthetic learning on the basis of open-ended problems a stronger effect on the achievement and improvement of mathematical creative thinking abilities than conventional learning. These results are consistent with the O.N. Kwon, J.S. Park and J.H. Park (2006) studies which suggest that open-ended problems with multiple 
answers and problem-solving strategies are effective in increasing divergent thinking. Similarly, mathematical groups that utilize highly active mathematical thinking skills with open-ended problems are also effective in fostering creative problem-solving abilities, unlike many traditional classes that focus on closed problems.

The result of descriptive analysis toward the achievement of students' mathematical creative thinking ability as a whole in open-ended problems based analytic-synthetic learning and conventional learning is in the medium category. However, when viewed from the average achievement of students' mathematical creative thinking abilities, open-ended problems based analytic-synthetic learning has a higher mean value than conventional learning. Therefore, openended problems based analytic-synthetic learning is more potential in developing students' mathematical creative thinking ability than conventional learning. The results of interviews with some students after conventional learning, they understand that a problem can be solved by various ways and even various answers through explanations and examples of problems that are solved together. However, they still find it difficult to solve a problem that demands a diversity of strategies and diversity of answers.

Other findings on the achievement of students 'mathematical creative thinking based on PMK levels in the two learning groups show that at each level (high, medium, and low), the achievement of students' mathematical creative thinking ability that have in open-ended problems based analytic-synthetic learning is better than students who gain conventional learning. Analyticsynthetic learning using open-ended problems as a basis for each meeting helps students in constructing knowledge and reasoning skills. Therefore, through this learning process of students' mathematical creative thinking can be more developed. This is in line with Lumsdaine and Lumsdaine (Yaqoob, 2012) that the creative thinking process as creative problem solving involves gathering information about some issues, analyzing them in order to define problems and understanding. Ideas are generated, elaborated and even synthesized to find a better solution. After that the results continue to be developed and tested in order to succeed in its application.

The achievement of students' mathematical creative thinking ability for each level (high, medium, and low) that get open-ended problems based analyticsynthetic learning is higher than students who get conventional learning. The achievement of mathematical creative thinking ability of low-level students who get open-ended problems based analytic-synthetic learning is higher than medium-level students who get conventional learning. This can happen because in open-ended problems based analytic-synthetic learning, the process of completion of open-ended problems is emphasized for discussion in groups. The analytical and synthetic process to solve problems is done by sharing ideas or ideas among students in groups. Highly skilled students are not allowed to dominate in problem solving, but they share their ideas with other students. If there are difficulties, the role of lecturers to open the minds of students by providing questions that can facilitate students towards the process of solving the problem. This is also reinforced by interviews with a low-skilled student that he finds it helpful to understand the problem given by the explanation of his group's friends. He also admitted that the questions asked by lecturers can recall the concept of the problem. It is not surprising, therefore, that in open- 
ended problems based analytic-synthetic learning at high level the achievement of students' mathematical creative thinking ability is in high criterion, while achievement at medium and low level is in medium criterion. Another case with conventional learning, the achievement of students' mathematical creative thinking ability at high and medium level is in medium criterion, and low level is in low criterion.

The results of the analysis indicate that open-ended problems based analytic-synthetic learning can further develop students' mathematical creative thinking ability at each PMK level compared with conventional learning. Student's mathematical creative thinking ability at High PMK level that gets open-ended problems based analytic-synthetic learning is more developed than medium and low PMK level. The ability of students' mathematical creative thinking at the medium PMK level is more developed than the low PMK level. Based on the results of this study indicate that in learning mathematics should pay attention to student PMK, because according to Mann (2005) that mathematics learning achievement, which reflects the intelligence, is one of the significant estimators for creativity.

Achievement in every aspect of students' mathematical creative thinking abilities in open-ended problems based analytic-synthetic learning is higher than that of students receiving conventional learning. In both lessons, the highest achievement is in the fluency aspect and the lowest on the originality aspect. In open-ended problems based analytic-synthetic learning, students' achievement on the aspect of fluency is high, while other aspects are moderate. Meanwhile, in conventional learning, the achievement on the aspects of fluency, flexibility, and elaboration is moderate, while the aspect of originality is low. This result can occur because based on an interview with one of the students from each learning group states that they generally have difficulty to solve problems unusually. They are average in solving the problem using the way that has been exemplified by the lecturer or the ways they have done in completing the Student Activity Sheet. These findings are similar to those of Risnanosanti (2010), Kartini (2011), and A. Suryana (2016).

From the test results related to the creative thinking ability of pre-service elementary school teacher, open-ended problems based analytic-synthetic learning can be used to develop students' mathematical creative thinking ability. This learning can develop every aspect of mathematical creative thinking ability especially on fluency aspect. This can be seen from the achievement of the ability of the fluency is quite high, while the aspects of flexibility, elaboration, and originality are medium. These results are of course not optimal, need attention to the PMK because it affects the learning outcomes. Therefore, before applying this learning the lecturer must reinforce the concept of PMK students first in order to obtain optimal results. Providing motivation and facilitating student difficulties in solving open-ended problems needs to be done primarily in bringing up aspects of novelty (originality).

\section{Disclosure statement}

No potential conflict of interest was reported by the authors.

\section{Notes on contributors}

Yeni Yuniarti - Indonesia University of Education 
Yaya S. Kusumah - professor, Indonesia University of Education, Indonesia

Didi Suryadi - professor, Indonesia University of Education, Indonesia

Bana G. Kartasasmita - professor, Indonesia University of Education, Indonesia.

\section{References}

Arikunto, S. (2005). Dasar-dasar Evaluasi Pendidikan. Jakarta: Bumi Aksara.

Badan Standardisasi Nasional Pendidikan (BSNP). (2006). Pedoman penyusunan kurikulum tingkat satuan pendidikan. Jakarta: Depdiknas.

Celik, D. \& dan Arslan, A.S. (2012). The Analysis of Teacher Candidates' Translating Skills in Multiple Representations. Elementary Education Online, 11(1), 239-250.

Chamberlin, S.A. \& Moon, S.M. (2005). Model-eliciting activities as tool to develop and identify creativity gifted mathematicians. Journal of Secondary Gifted Education, 17(1), 37-47.

Chareka, O. (2010). A matter of prior knowledge: Canadian young children's conceptions about the future in the global community. International Electronic Journal of Elementary Education, 2(2), 287-303.

Craig, J. (2015). Assessing the Relationship between Questioning and Understanding to Improve Learning and Thinking (QUILT) and Student Achievement in Mathematics: A Pilot Study. Virginia: Charleston.

Hailikari, T. (2009). Assessing University Students'Prior Knowledge. Implications for Theory and Practice. Helsinki: Helsinki University Print.

Hyman, B. (1993). Measuring What Counts: A Conceptual Guide for Mathematics Assessment. Washington: National Academies Press.

Kartini. (2011). Peningkatan Berpikir Kritis dan Kreatif serta Belief Matematis Siswa Sekolah Menengah Atas melalui Pembelajaran Inkuiri Model Alberta. Diterbitkan: SPS UPI.

Khoiri, W., Rochmad, A. \& Cahyono, A.N. (2013). Problem Based Learning berbantuan Multimedia dalam Pembelajaran Matematika untuk meningkatkan Kemampuan Berpikir Kreatif. Unnes Journal of Mathematics Education, 2(1), 114-121.

Kumiati. (2014). Peningkatan Kemampuan Berpikir Kritis dan Kreatif Matematis serta Soft Skill Mahasiswa Pendidikan Guru SD melalui Pendekatan Pembelajaran Kontekstual. Diterbitkan: SPS UPI.

Kwon, O.N., Park, J.S \& Park, J.H. (2006). Cultivating Divergent Thinking in Mathematics through an Open-Ended Approach. Asia Pacific Education Review, 7(1), 51-61.

Lee, I.R. \& Kemple, K. (2014). Preservice Teachers' Personality Traits and Engagement in Creative Activities as Predictors of Their Support for Children's Creativity. Creativity Research journal. 26(1). 82-94.

Mann, E.L. (2005). Mathematical Creativity and School Mathematics: Indicators of Mathematical Creativity in Middle School Students. Direct access: http://www.gifted. uconn.edu/Siegle/

Mann, E.L. (2006). Creativity: The Essence of Mathematics. Journal for the Education of the Gifted, $30(2), 236-260$.

Mulyana, T. (2008). Pembelajaran Analitik Sintetik untuk Meningkatkan Kemampuan Berpikir Kritis dan Kreatif Matematik Siswa Sekolah Menengah Atas. Diterbitkan: SPS UPI.

Munandar, U. (2014). Pengembangan Kreativitas Anak Berbakat. Jakarta: Rineka Cipta.

Munandar, U. (2003). Kreativitas \& Keberbakatan. Strategi Mewujudkan potensi kreatif \& Bakat. Jakarta: PT Gramedia Pustaka Utama.

Nadjafikhah, M. \& Yaftian, N. (2013). The frontage of Creativity and Mathematical Creativity. Procedia - Social and Behavioral Sciences, 90, 344-350.

Nadjafikhah, M., Yaftian, N. \& Bakhshalizadeh, S. (2012). Mathematical creativity: some definitions and characteristics. Procedia - Social and Behavioral Sciences, 31, 285-291.

National Research Council. (2012). Education for Life and Work: Developing Transferable Knowledge and Skills in the 21st Century. Committee on Defining Deeper Learning and 21 ${ }^{\text {st }}$ Century Skills, James W. Pellegrino and Margaret L. Hilton, Editors. Board on Testing and Assessment and Board on Science Education, Division of Behavioral and Social Sciences and Education. Washington: The National Academies Press.

Neumann, C.J. (2007). Fostering creativity-A model for developing a culture of collective creativity in science. EMBO Reports, 8(3), 202-206. 
Noer, S.H. (2011). Kemampuan Berpikir Kreatif Matematis dan Pembelajaran matematika Berbasis masalah Open-Ended. Jurnal Pendidikan Matematika, 5(1), $104-111$.

Nohda, N. (2000). Teaching by Open-Approach Method in Japanese Mathematics Classroom. Proceedings of the Conference of the International Group for the Psychology of Mathematics Education, 1, 23-27.

Risnanosanti. (2010). Kemampuan Berpikir Kreatif Matematis dan Self Efficacy terhadap Matematika Siswa Sekolah Menengah Atas (SMA) dalam pembelajaran Inquiri. Diterbitkan: SPS UPI.

Shahrill, M. \& Clarke, D.J. (2014). Brunei Teachers' Perspectives on Questioning: Investigating the Opportunities to "Talk" in Mathematics Lessons. International Education Studies, 7(7), 1-17.

Sriraman, B. (2005). Are giftedness \& creativity synonyms in mathematics? An analysis of constructs within the professional and school realms. The Journal of Secondary Gifted Education, 17, 20-36.

Starko, A.J. (2014). Creativity in the Classroom Schools of Curious Delight. New York: Routledge.

Sternberg, R.J. (2006). The Nature of Creativity. Creativity Research Journal. 18(1), 87-98.

Suastika, K. (2017). Mathematics Learning Model of Open Problem Solving to Develop Students' Creativity. International Electronic Journal of Mathematics Education. 12(6), 569-577.

Supriadi. (2014). Mengembangkan Kemampuan dan Disposisi Pemodelan serta Berpikir Kreatif Matematis Mahasiswa PGSD melalui Pembelajaran Kontekstual Berbasis Etnomatematika. Diterbitkan: SPS UPI.

Suryana, A. (2016). Meningkatkan Advanced Mathematical Thinking dan Self Renewal Capacity Mahasiswa melalui Pembelajaran Model PACE. Pendidikan: Universities Pendidikan.

Trilling, B. \& dan Fadel, C. (2009). 21 st Century Skill: Learning for Life in Our Times. San Francisco: Jossey-Bass A Wiley Imprint.

Yaqoob, M. (2012). Developing Creative Thinking: Using a Cognitive Teaching Model in Literature Classroom. The International Journal of Learning. 18(6), 71-82. 